\title{
Synthesis
}

International Scientific Conference of IT and Business-Related Research

\section{TOWARDS THE PROBLEM OF EXISTENCE OF THE SCIENTIFIC THEORY OF AUDIT}

\section{O PROBLEMU POSTOJANJA NAUČNE TEORIJE REVIZIJE}

\author{
Pavel P. Baranov \\ Department of Finance, Accounting and Auditing, Siberian State Industrial University \\ 42 Kirov St., Novokuznetsk, Russian Federation 654000
}

\begin{abstract}
:
This paper aims to formulate and justify the hypothesis that the lack of scientific theory of audit is a factor that provokes doubts in the institutional integrity of audit. The author discloses arguments, proving an imbalance and fragmented nature of the existing provisions in the field of audit as a system of scientific knowledge. These arguments indicate the need for an integrated interdisciplinary research, aimed at creating the scientific theory of audit, as well as organized field of economic sciences. In addition, the author formulates the basic tasks for forming the theory of auditing science and the main issues that hinder its formation. Different points of view of various scientific schools regarding the structure, mutual correlation and the content of the main attributes of the scientific theory of audit are characterized and critically analyzed in this paper. The author offers and describes the directions for overcoming the internal and external contradictions of auditing science and practice on the basis of both foreign and domestic research findings.
\end{abstract}

\section{Key words:}

key problems of forming the theory of auditing science, the issue of existence of auditing science, reasons for institutional insolvency of audit, subject and method of audit, form and structure of scientific knowledge.

\section{INTRODUCTION}

From a historical point of view, an audit is one of the youngest types of economic activity that became legal in the middle of the nineteenth century after the British Companies Act came into force. As regards the auditing practice in the Russian Federation, it gained official legal recognition in 1993, when the Russian Presidential Decree No. 2263 «About provisional rules of audit activity» was issued. The analysis of the situation in the national economic systems in various periods provides the opportunity to detect reasons for its occurrence within the phenomena, accompanied by the increased turbulence of economic space and information risk in economics and managerial decision-making. For instance, the intensive audit expansion in Western Europe in the nineteenth century was the result of the fourth management revolution (Rumyantzeva et al., 1995), when management and ownership were separated, and the community of professional managers created. Obviously, the distancing of owners from business and information processes generated contradictory interests of owners and managers. This conflict of interest was caused by the traditional approach to motivation of managers based on the relationship between the efficiency of administrative work and efficiency of managed business. The application of such motivation model is almost inevitable, but it creates a fertile ground for fogging and falsify-

\section{Apstrakt:}

Ovaj rad nastoji da obrazloži i opravda hipotezu da odsustvo naučne teorije revizije predstavlja faktor koji izaziva sumnju u institucionalni integritet same revizije. Autor navodi argumente koji ukazuju na disbalans i fragmentiranu prirodu postojećih odredbi iz oblasti revizije kao sistema naučnih znanja. Ovi argumenti navode na zaključak da postoji potreba za integrisanim interdisciplinarnim istraživanjem u cilju stvaranja naučne teorije revizije kao i organizovane oblasti ekonomskih nauka. Pored toga, autor formuliše osnovne zadatke za definisanja teroije revizorske nauke kao i prepreke koje se mogu javiti na tom putu. Ovaj rad kritički sagledava i obrađuje stavove koje zagovaraju različite naučne škole vezano za strukturu, uzajamnu povezanost i sadržaj glavnih atributa naučne teorije revizije. Autor ukazuje na moguće smernice za prevazilaženje internih i eksternih protivrečnosti unutar revizorske nauke i prakse na osnovu istraživanja sprovedenih u zemlji i inostranstvu.

\section{Ključne reči:}

ključni problemi kreiranja naučne teorije revizije, pitanje postojanja revizije kao nauke, razlozi za institucionalnu nelikvidnost revizije, predmet i metod revizije, forma i struktura naučnog znanja.

ing of accounting data and financial reports, used in the owner's analysis for making the conclusions on the financial and assets position of the owned business units and business results. However, the most important fact is that the owner makes a decision on the form and amount of manager remuneration based on such conclusions.

It was not possible to overcome such contradictions without the intervention of the third entity in the bundle «owner - manager». This third entity was an independent auditor, trained to use special methods for the purpose of assessing the reliability of economic information, represented by managers in the form of financial reports used by the owners when shaping their conduct in relation to their business.

It should be noted that similar reasons awakened an audit in the new Russia. The most widespread variant of privatization of the state enterprises assuming their primary transformation in open joint stock companies with huge army of shareholders had exactly the same consequences on the domestic economy at the end of the XX century as the fourth management revolution of the XVIII century had on Western European countries. In particular, the property structure, which was washed away at an initial post-privatization stage (when the share capital was formally distributed between the tremendous amount of members of labor collectives), caused publishing of the Russian Presidential Decree «About provisional rules of auditing activities» with a norm for obligatory audit of open joint stock companies. 
Actually, the introduction of this norm was recognition of information risk growth in the new Russian economy and was urged to protect interests of new owners against possible risk.

However, at the end of the XX - beginning of the XXI century, the question of institutional insolvency of auditor's activity was brought up even more often in foreign and domestic economy. The reasons for the crash of a number of multinational companies were found in the low quality of audit, expansion of «black audit» in Russia and other similar attributes led to doubt in the ability of an audit to protect economy, society and state in general from the risk caused by doubtful data getting into an information field of decision-making by financial statement users. In many respects, this doubt attracted special attention of regulators and professional community, including its scientific component - the scientists dealing with the issues of accounting, economic analysis and audit. Thereof, doubt in insolvency of practical audit developed into a heated debate about the existence of audit as an organized science. As for the existence of scientific theories of accounting and economic analysis, these theories admit categorically all scientific criteria, but it is impossible to tell the same for the scientific theory of audit. The arguments for such a conclusion are provided by the contents of the Russian State educational standards of higher education in the specialty 080109 «Accounting, Analysis and Audit» in which «The theory of accounting» and «The theory of the economic analysis» are allocated as separate disciplines of a federal component. However, the theory of audit in this standard is absent even as a didactic element of the content of discipline "Audit". By recognizing such a situation, it is difficult to disagree with the American scientists Mautz and Sharaf, who stated in their wellknown monograph «The Philosophy of Auditing» that there is something clumsy in the profession that doesn't have a scientific basis in a form of the detailed theory characterized by common structure (Mautz \& Sharaf, 1961). It is interesting that domestic scientists came to the same conclusion concerning the status of the scientific theory of audit with a delay of practically fifty years. The publications of $\mathrm{PhD}$ experts in the field of economic sciences, Gutzait (2010) and Sheremet (2006), laid the foundation to discuss a problem of audit identification as a science in the Russian scientific community at the beginning of the new century.

However, this problem was so difficult that neither the first nor the second decade of the century were marked by any harmonious point of view offering vision of auditor's science. For fifteen incomplete years of the new millennium in Russia, there has been no doctoral dissertation devoted to the complex analysis and research in the given field. Some exception, perhaps, are dissertation studies of Gutzait «Actual problems of Audit (the basic concept, decision, methodology) " and Azarskaya "The theory and methodology of ensuring quality of audit». However, it's notable that even these dissertations didn't disclose the answer to a question of a form, structure and contents of the theory of audit as a system of scientific knowledge. Also, it is important to focus on the lack of educational literature deserving a close attention according to the theory of audit - the section with such a title was present only in the textbook of prof. Podolsky (thus as fairly noticed by prof. Sheremet (2006), the theory of audit isn't given in this section). In addition, some hopes aroused after the announcement of the manual with a promising title «The theory of Audit» by Zhminko et al. (2013), which unfortunately didn't come true: the book represents a good interpretation of the existing auditing standards with control materials and interesting impregnation of historical data. However, the theory of audit as an organized system of knowledge (except for a mention of the principles of audit and well-known option of its positioning in the field of control types) is not presented in this textbook. Thus, the problem of existence of auditing science remains open, since this science as the system of knowledge isn't described, its structure and content aren't designed and the nature of its elements isn't clearly described in the scientific community (not only in Russia, but also abroad). As for the representative cohort of critics of audit, such a situation brought to them strong reasons for denial of scientific fundamentals of auditor's practice and also for the reference of de-facto existing provisions of audit to the area of «scientific diablerie».

In the current circumstances, it's necessary for the scientific community to start with the new kind of research in the direction of "collecting", integrating and systematizing the existing elements of audit science, forming of its structure, internal and external relations, defining and filling of the existing lacunae and gaps. Historical research of accounting and audit theories development in Russia and abroad, whose results are particularly characterized in (Baranov, 2012, 2013), allow to predict the potential success of similar work in case of fulfillment of a number of basic conditions and requirements.

\section{RESULTS AND DISCUSSION}

From the author's point of view, it's very important to use the general methodological approach to the process of organizing and carrying out relevant research in the field of auditing theory formation. It will allow to get clear architecture of theory and define framework directions for solving a number of key problems such as:

1. Formation of the general vision of audit science and its relationship with other sciences.

2. Development of alternative variants of the organization of auditing science.

3. ustification and description of the structure of scientific knowledge of audit.

4. Development and argumentation of criteria of scientific character of audit knowledge.

5. Definition and adoption of forms of scientific knowledge for the purpose of presenting theoretical research results.

It's obvious that the listed tasks are fundamental research problems and the solution to each of them will naturally cause problems of the second order, but some of these tasks can already be formulated in a general view.

The solution to the first system task (formation of the general vision of audit science) has to give answers to the following questions: what is the design of this science as the organized area of scientific knowledge, what is its subject and its communication with other sciences? It's pleasant to note that certain approaches to vision of these aspects have already been offered by both foreign and domestic scientists. However, the authors believe that prior to giving short characteristics to their views, it is necessary to briefly devote attention to the proper use of scientific terminology, as the painful basic moment of formation of any science. Unfortunately, this rather widespread «illness of scientific growth» chronically pursues audit and shows its symptoms even by the most cursory examination. In particular, we mention an equal use in the scientific and professional lexicon of such terms, as " audit science », «the theory of audit», "the concept of audit» (in order to complete the picture we can add also «an audit paradigm»). It is obvious that expenses of word usage are partly caused by the desire to give pseudoscientific character to the existing provisions of audit, but consequences of such free use of classical terminology of philosophy of science just stimulate entropy, generating interpretation contradictions in the scientific community. 
Methodological approach assumes that the science is defined by a subject of its study. In addition, it tries to explain how various theories (which are unequally explaining laws of development of a subject) can coexist in this context, and beyond its limits, clashing or supplementing each other. The term «concept» is very debatable. As on the etymology "concept» the main option of interpretation is characterized as a certain way of understanding, the treatment of the examined phenomena (Lapina \& Matalina, 2008) that significantly pulls together «concept» with «theory». Thus, it should be noted that the concept in scientific life is quite often only a component of the scientific theory that covers only one subsystem or an element of an object of science and offers possible explanations regarding the nature of this subsystem, its communication with other subsystems and subjects of an environment. Also, the use of the term "paradigm» in the system of scientific knowledge of an audit is not less problematic. This case attracted close attention of the famous Russian scientist prof. Sokolov (2005) whose evolution of views on positioning and interpretation of the category "paradigm» in the accounting theory started from the recognition of the treatment of the given concept. Sokolov appeals to the author of «Structure of scientific revolutions» Thomas Kuhn (2003) who interpreted a paradigm as a «set of belief, values, technical means, etc. shared by the members of some community». As researchers of scientific heritage of prof. Sokolov note, in the course of the creation of the theory of change of accounting paradigms, he "constantly changed interpretation of the concept "paradigm», trying to adapt Kuhn's definition for accounting» (Karelskaya \& Zuga, 2012), and, finally, stopped on two treatments. First of these treatments (scientific focused) considers a paradigm as the concept recognized as all, «... which during certain time gives model of statement of problems and their decisions to scientific community», and the second (practice-focused) characterizes this concept as «those general provisions in which a certain community of people» trusts (Karelskaya \& Zuga, 2012). Unlike the area of the accounting theory, in audit nobody was engaged in serious research of the category "paradigm» so far though this concept has been used «regularly and with great pleasure».

It's not so difficult to notice, that even such superficial analysis of the basic categorical device of audit shows abnormal terminologies entropy provoking the conflicts of interpretations which inevitably cause a "pro-slipping» of development of scientific basis of auditor activity. According to the authors' opinion, the solution to the problem of streamlining of the contents and determination of hierarchy of the main categories of audit has to be carried out by scientists-auditors in a close bundle with the experts in the field of philosophy and epistemology of science. It is obvious that nowadays only such a kind of tandem is capable of providing logically harmonious and consistent results with minimum expenses.

Coming back to the problem of formation of the general vision of audit science and its communications with other sciences, we should note the work of domestic scientists Sheremet and Gutzait, who have given an impulse to the process of integration of scientific knowledge of audit. Perhaps, for the first time, the importance of this process for Russia was comprehensively proved in 2006 by professor Sheremet in the report on "A problem of the theory of audit» at the International scientific and practical conference «Tatur' Readings» devoted to the theme «Reforming of Accounting, Audit and Accounting Education according to the International Standards» (Sheremet, 2006). Actually, the specified report disclosed the whole complex of problems of search and theoretical description of the endemic (inherent only to audit) lines, definition of its nature, contents, subject, object and method. In one word, it disclosed all audit science signs without which demarcation of the theory of audit and understanding of its communications with other sciences is impossible. It is not so difficult to agree with the assessment of the domestic scientist, who noted that by the beginning of a new eyelid «the general principles and rather detailed rules of audit, the international and domestic standards of audit and some auditor services are developed». Besides this, the attention is attracted by the sharpness of Sheremet' question about the background for allocation and consideration of audit as an independent science and practice as it is accepted for accounting, economic analysis, control and audit. The further logic of the cited report actually declares the lowest level of scientific formalization of the theory of audit: thesis of the report state a need of identification of a place of audit in system of economic sciences, in a system of management, functional sciences, in the monitoring system in general and financial control, in particular. Professor Sheremet emphasizes the relevance of definition of audit as a science and practice, justifications of a subject and a method of audit as a science, descriptions of essence of audit and auditor activity, modelling of audit communication with an assessment of efficiency of an economic activity and the solution of other standard questions for the characteristic of the scientific theory.

Certainly, the process of structural design of audit scientific knowledge is long and difficult, assuming recurrent critical analysis, continuous return to basis and an assessment of compliance of the received results to criteria of a scientific goalsetting. In the current circumstances, it is obviously important to create some initial theoretical construction that can be considered a starting point in the process of design of audit science. The analysis of development of scientific basis of audit allows accepting the five-level structure of audit science offered in the second half of the XX century by American scientists Mautz and Sharaf. Fig. 1 characterizes this structure in the form of the hierarchical and logical scheme.

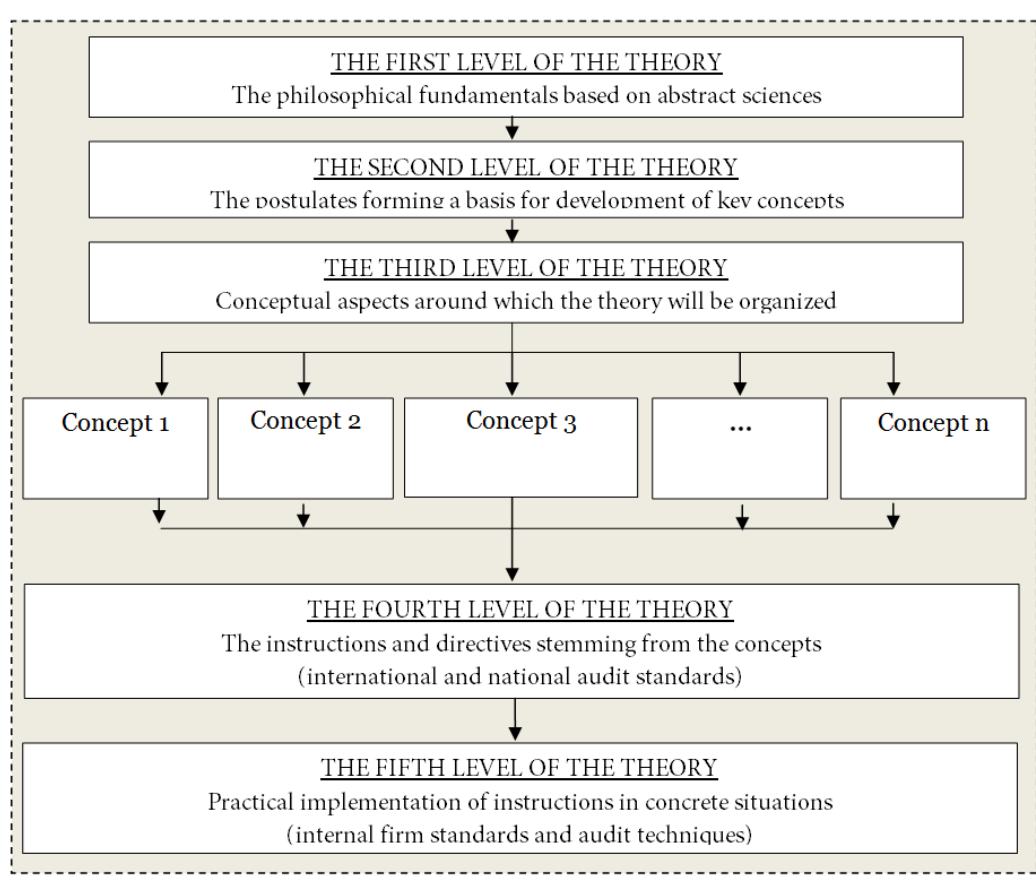

Figure 1. The structure and content of scientific theory of auditing 
For the purpose of providing an explanation of the design offered by the American experts, it is expedient to provide some quotes from their monograph «The Philosophy of Auditing» disclosing essence of the approach used for theoretical design of scientific knowledge: «Auditing deals with abstract ideas; it has its foundations in the most basic types of learning; it has a rational structure of postulates, concepts, techniques, and precepts; adequately understood, it is a rigorous intellectual study worthy to be called a "discipline" in the current sense of that term. Thus, auditing provides opportunities for and even demands strenuous intellectual effort. Based on such efforts, it is possible to discover and comprehend the underlying theory and use it to contribute to the filed.» (Mautz \& Sharaf, 1961, p. 16). As can be seen from the above- cited, the first of numerous merits of the aforementioned American authors is justification of reasons of audit consideration as a science. By developing the «audit philosophy», scientists start from science methodology that allows them to describe the theory of audit so systemically that such a description forms the strong basis for development of scientific research of an audit perspective in the future.

According to Mautz and Sharaf, audit can be characterized as the five-level structure including:

1. The philosophical fundamentals based on abstract sciences;

2. The postulates forming a basis for development of essential concepts;

3. Conceptual aspects (concepts) around which the theory will be organized;

4. The instructions representing more or less accurate practical directives;

5. Practical implementation of instructions in concrete situations.

It is obvious that the first three levels of this hierarchical design describe no other than the theory of audit, while the fourth and fifth level cover auditor's practice. It is necessary to pay attention to the analogy arising when comparing this approach to consideration of audit with accounting interpretation used, in particular, by professor Sokolov, who allocated two layers of accounting - accountology (theory) and book-keeping (practice).

Mautz and Sharaf saw the main objective of the theory of audit in creation of a basis for decision-making, or, in other words, «keys» to the solution of the existing practical problems. Their arguments regarding the scientific nature of audit are very interesting and important, and despite bulkiness of the quote reflecting this reasoning, it is expedient to give it completely: « Auditing is also an "applied" discipline, and as an applied discipline models its "principles" or basic theory on many other fields, there is always the possibility that it will lose sight of its connection with and dependence on the more basic or abstract fields of study. Thus, it may neglect its theory and give a disproportionate part of its attention to applications and immediate day-to-day problems. This is always unfortunate because the strength of any discipline lies in its foundations. Auditing can scarcely be accused of neglecting its theory, because it is still so young and may never become really aware of its relationship with the fundamental disciplines.

Nonetheless, the danger is present. We have a strong tendency in auditing to assume a pragmatic approach. Whatever works well is adopted and strongly advocated, while what has not been yet found applicable has little appeal. This is a natural tendency to some extent, but we still need to keep it within bounds. Namely, we must continuously test our practices and procedures, not only in real life, but against the theory which underlies auditing. Also, we should continually explore the the- ory for possible approaches to both new and old issues. If we forget the theoretical foundation of auditing and let it dwindle to a mere collection of rote procedures and practices reminiscent of its early history, it will not only lose stature in the eyes of the world, but will forfeit the best method of solving its most perplexing problems» (Mautz \& Sharaf, 1961, p. 17). From the author's point of view, the given reasoning convincingly proves that Mautz and Sharaf were pioneers who sounded a problem of formation of the audit theory as the major scientific task. They were the first who drew attention to the specifics of communication of audit and other sciences and characterized consequences of various scenarios of its development.

\section{SUMMARY}

The aforementioned analysis shows that the thesis about the absence of scientific theory of audit is far from the truth. It is only apparent that the elements of audit science used in practice are disintegrated and poorly proved. First of all, their disintegration doesn't give the chance to form a judgment about the existence of audit as full-fledged science, and the weakness of the scientific argument of its contents provokes doubts in «scientific character» of audit knowledge. At the same time, the results of both foreign and domestic scientific schools allow to order terms, framework, define and describe the format of the scientific theory of audit, its structure, contents and communication of its components. There are strong grounds for believing that active efforts of experts in the field of audit and philosophy of science, economic theory, logic and theory of decision-making, may provide solutions to the given issues. In addition, based on the wide publication and discussion of results of their joint research, the most serious problem - the problem of recognition of auditor's science - can be solved in the foreseeable future.

\section{REFERENCES}

Baranov, P.P. (2012). Threat of loss of the institutional status of auditor activity in the conditions of stagnation of the theory of audit. The Siberian financial school, 6, 144-150.

Baranov, P.P. (2013). Genesis of the theory of audit: prerequisites of origin, development problem, current state. Innovative development of economy, 2, 85-101.

Gutzait E.M. (2010). Audit and other sciences. Auditor. 10, 15-26.

Karelskaya, S.N., Zuga, E.I. (2012). Definition of paradigms of accounting in works of Ya.V. Sokolov. Finance and business, 4, 174-185.

Kuhn, T. (2003). The Structure of scientific revolutions. Moscow: AST.

Lapina, I., \& Matalina E. (2008). Big encyclopaedic dictionary. Moscow: AST.

Mautz, R.K., \& Sharaf, H. (1961). The Philosophy of Auditing. Sarasota, FL: American Accounting Association.

Rumyantseva, Z.P., Salomatin, N.A., \& Ackberdin, R.Z. (1995). Management of an organization. Moscow: INFRA-M.

Sheremet A.D. (2006). Reforming of accounting and audit according to the international standards. Auditor sheets, 8 , 4-12.

Sokolov, Ya.V. (2005) Three paradigms of double-entry bookkeeping. Accounting. 15. 49-53.

Zhminko, S. I., Shvyreva, O. I., Safonova, M.F. \& Kalinina, I.N. (2013). Theory of audit: manual. Rostov-on-Don: Phoenix. 